Arq. Bras. Med. Vet. Zootec., v.71, n.4, p.1395-1402, 2019

\title{
Beef cattle performance on signal grass pastures deferred and fertilized with nitrogen
}

\author{
[Desempenho de bovinos em pastos de capim-braquiária diferidos e adubados com nitrogênio] \\ P.L. Amorim ${ }^{1}$, D.M. Fonseca ${ }^{2}$, M.E.R. Santos $^{3}$, R.M. Pimentel ${ }^{4}$, \\ J.P.P. Rodrigues ${ }^{5}$, F.H.M. Chizzotti ${ }^{2}$, C.G. Vitor ${ }^{6}$ \\ ${ }^{1}$ Universidade Federal do Alagoas - Rio Largo, AL \\ ${ }^{2}$ Universidade Federal de Viçosa - Viçosa, MG \\ ${ }^{3}$ Universidade Federal de Uberlândia - Uberlândia, MG \\ ${ }^{4}$ Universidade Federal Fluminense - Rio de Janeiro, RJ \\ ${ }^{5}$ Universidade Federal do Sul e Sudeste do Pará - Xinguara, PA \\ ${ }^{6}$ Universidade Federal de Minas Gerais - Belo Horizonte, MG
}

\begin{abstract}
The effect of four nitrogen levels $\left(0,40,80\right.$ and $\left.120 \mathrm{~kg} \mathrm{~N}^{-1}\right)$, applied before deferment on the beef cattle production and structural variables on Urochloa decumbens (signal grass) were assessed from January to October 2012 and from January to September 2013. A randomized block design with three replicates was adopted, in an arrangement of repeated measures in time (grazing period). An interaction effect between nitrogen level and grazing period was observed on extended-plant height and herbage mass. As the nitrogen levels were increased, extended-plant height, herbage mass, total herbage allowance, and efficiency of conversion of fertilizer into herbage were increased. Throughout the grazing period, pasture height, extended-plant height, percentage of leaves, herbage and morphological components allowance, and percentages of leaves and stems in the herbage apparently selected by the animal decreased. Nitrogen levels had no effect on average daily gain or gain per area in the first year. A fixed deferment period with increasing levels of nitrogen fertilization on signal grass pastures does not influence the average daily gain per animal, reduces the efficiency of the nitrogen fertilizer and negatively changes the structural characteristics of the pasture.
\end{abstract}

Keywords: average daily gain, deferrment, seasonality, tropical pasture, Urochloa decumbens

\section{RESUMO}

Foi avaliado o efeito de quatro doses de nitrogênio $\left(0,40,80\right.$ e $\left.120 \mathrm{~kg} \mathrm{~N} \mathrm{ha}^{-1}\right)$, aplicadas antes do diferimento, sobre o desempenho de bovinos e as características estruturais de Urochloa decumbens (capim-braquiária), de janeiro a outubro de 2012 e de janeiro a setembro de 2013. Um delineamento de blocos ao acaso foi utilizado em arranjo de medidas repetidas no tempo (período de pastejo). Foi observada interação entre doses de nitrogênio e período de pastejo na altura da planta estendida e na massa de forragem. As doses de nitrogênio incrementaram a altura da planta estendida, a massa de forragem, a oferta de forragem e a eficiência de conversão do nitrogênio em forragem. No decorrer do período de pastejo, a altura do pasto, a altura da planta estendida, a porcentagem de lâminas foliares, a oferta de forragem e dos seus componentes morfológicos e a porcentagem de lâminas e colmos da forragem aparentemente selecionada pelos animais diminuíram. As doses de nitrogênio não exerceram efeito sobre o ganho diário e o ganho diário por área no primeiro ano. O período de diferimento fixo com aumento das doses de nitrogênio em pastos de capim-braquiária não influencia o ganho diário por animal, reduz a eficiência da adubação nitrogenada e afeta negativamente a estrutura do pasto.

Palavras-chave: ganho médio diário, diferimento, sazonalidade, pasto tropical, Urochloa decumbens

Recebido em 1 de agosto de 2017

Aceito em 8 de janeiro de 2019

E-mail: philipe.amorim@ceca.ufal.br 


\section{INTRODUCTION}

The deferment is a useful management tool in tropical conditions and consists of removing grazing animals from a given area of the pasture in the final third of the rainy season aiming to produce forage to be grazed on during the dry period and forage scarcity. Several management actions can be taken in pasture deferment, involving the time, period, and pasture height at the beginning of deferment, supplementation, or nitrogen fertilization, which should all be observed to ensure good results. These actions aim to provide deferred pastures with good structural and qualitative characteristics and greater potential to improve animal performance.

Nitrogen fertilization allows an increase in forage production during the deferment period and consequently in the stocking rate at the pasture deferred during the winter period, since lower stocking rates are commonly used in this period (Teixeira et al., 2011). However, greater nitrogen $(\mathrm{N})$ fertilization may negatively affect the structure of the deferred pasture, resulting in an excessive increase in forage mass, forage losses, percentage of stems, dead forage, and reducing the percentage of live leaves, in addition to increasing $\mathrm{N}$ losses to the environment. These alterations in the pasture structure may compromise animal performance, resulting in a lower efficiency of conversion of the $\mathrm{N}$ fertilizer into forage and animal product, which may elevate the costs of animal production. Therefore, the evaluation of how $\mathrm{N}$ fertilization affects deferred pasture and animal performance is important to determine better deferment strategies. The aim of this study was to evaluate the sward structure and beef cattle production on signal grass pastures fertilized with $\mathrm{N}$ levels in the beginning of the deferment period.

\section{MATERIALS AND METHODS}

The ethics committee of the Universidade Federal de Viçosa approved the management procedures (protocol no. 052/2014). The experiment was carried out from January to October 2012 (year 1) and from January to September 2013 (year 2) in the Forage Crops Section of the Department of Animal Science at Federal University of Viçosa, located in Viçosa, MG, Brazil (2045' S, 42 ${ }^{\circ} 51^{\prime}$ W; 651 m altitude). Climatic data were collected throughout the experimental period (Figure 1) at the meteorological station of the Federal University of Viçosa.

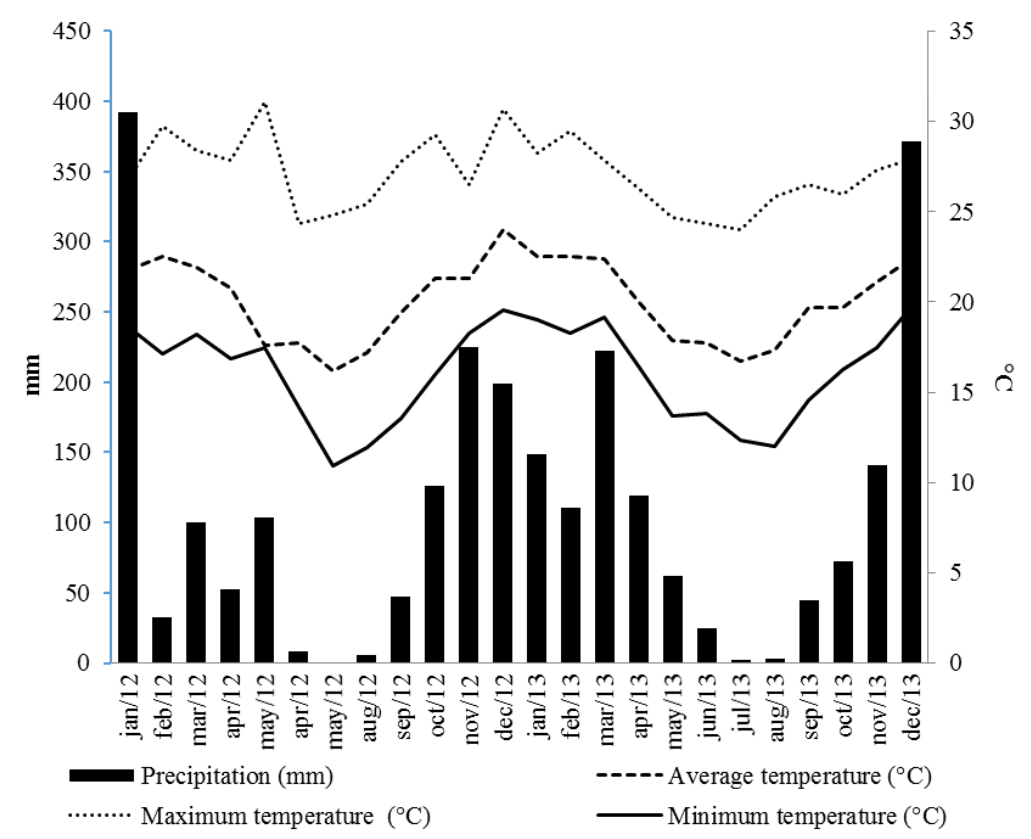

Figure 1. Rainfall, average, maximum and minimum temperature during the experimental trial. 
The experimental area consisted of a pasture of Urochloa decumbens cv. Basilisk (signal grass), with 8 (year 1) and 12 (year 2) paddocks (experimental units) with dimensions ranging from 2,524 to $4,050 \mathrm{~m}^{2}$, totaling approximately four hectares, in addition to a reserve area with approximately 0.5 ha.

Samples of the soil from the experimental area were collected from the $0-20 \mathrm{~cm}$ layer and the following results were obtained: $\mathrm{pH}\left(\mathrm{H}_{2} \mathrm{O}\right)=$ 4.98; $\mathrm{P}=2.02 \mathrm{mg} \mathrm{dm}^{-3}$ (Mehlich-1); $\mathrm{K}=86.75 \mathrm{mg}$ $\mathrm{dm}^{-3}$ (Mehlich-1); $\mathrm{Ca}^{2+}=1.6 \mathrm{cmol}_{\mathrm{c}} \mathrm{dm}^{-3} ; \mathrm{Mg}^{2+}=$ $0.53 \mathrm{cmol}_{\mathrm{c}} \mathrm{dm}^{-3} ; \mathrm{Al}^{3+}=0.38 \mathrm{cmol}_{\mathrm{c}} \mathrm{dm}^{-3}(\mathrm{KCl}$ $1 \mathrm{~mL} \mathrm{~L}^{-1}$ ); effective $\mathrm{CEC}=6.64 \%$; $\mathrm{CEC}$ at $\mathrm{pH}$ $7.0=9.06 \%$; base saturation $=26.25 \% ; \mathrm{m}=$ $14.37 \%$ and remaining $\mathrm{P}=21.07 \mathrm{mg} \mathrm{L}^{-1}$. Four $\mathrm{N}$ levels were evaluated $(0,40,80$, and $120 \mathrm{~kg} \mathrm{~N}$ $\mathrm{ha}^{-1}$ ) in the form of urea, applied by broadcasting at the beginning of deferment, in a randomized block design with two (year 1) and three (year 2) replicates.

In the beginning of January 2012 and 2013, phosphate fertilization was applied by broadcasting, using single superphosphate. From January to the beginning of March, in 2012 and 2013, pastures were managed under continuous grazing, with a variable stocking rate aiming to keep the average pasture height at approximately $25 \mathrm{~cm}$ (Santos et al., 2011a). From early March to the beginning of the deferment period (03.31.2012 and 03.26.2013 in years 1 and 2, respectively), pastures were managed to be lowered to an average height of $20 \mathrm{~cm}$, and were kept in this condition by increasing the stocking rate. Before the beginning of the pasture deferment, together with the application of $\mathrm{N}$ fertilizer, potassium fertilization $\left(50 \mathrm{~kg} \mathrm{ha}^{-1} \mathrm{~K}_{2} \mathrm{O}\right)$ was also applied by broadcasting, as potassium chloride.

After 105 and 78 days of deferment in years 1 and 2, respectively, the use of the deferred pastures began, with animals being placed in the paddocks. Deferred pastures were used for 91 and 84 days of grazing for years 1 and 2, respectively. During this period, the pastures were managed under continuous grazing and a fixed stocking rate. Seventeen and twenty-nine uncastrated crossbred ( $1 / 2$ Nellore $\times 1 / 2$ Guzerat $)$ steers averaging $227 \pm 14.0 \mathrm{~kg}$ and $2467.3 \mathrm{~kg}$ of body weight (BW) were used in years 1 and 2 , respectively. All animals had free access to mineral supplement in wooden troughs. Steers were distributed in the paddocks systematically, due to the variation in the size of the paddocks, aiming to keep the initial stocking rate between 3 and 3.5 AU ha ${ }^{-1}$ in all paddocks, with a minimum number of two animals per experimental unit. Animals were weighed, after $15 \mathrm{~h}$ of fasting, before being distributed into the experimental units and at the end of the period of use of the deferred pasture.

To evaluate the pasture and extended-plant heights, herbage mass, tiller population density, and animal grazing simulation, samples were collected on the first day of use of the deferred pasture and every 28 days until the end of the period of use of the pasture.

Pasture height (PH) and extended-plant height $(\mathrm{EPH})$ were measured in 30 random points per experimental unit. The height at each point was determined using a ruler, considering the distance between the soil level and the leaf horizon. Extended-plant height was measured by extending the tillers of the signal grass vertically and recording the longest distance from the soil to the apex of the tillers. The falling index (FI) of the plants was calculated as the division between EPH and PH (Santos et al., 2009b).

Forage mass (FM) was estimated based on the collection of three samples in areas representing the average condition (height) of the pasture in each paddock. In each sampling site, the tillers within a 0.40-m-sided rebar frame were harvested at the soil level. Each sample was packed in a labeled plastic bag and taken to the laboratory, where they were weighed and subdivided into two sub-samples. To estimate the dry matter content one of the sub-samples was weighed, packed in a paper bag, and dried in a forced-air oven at $55^{\circ} \mathrm{C}$ for $72 \mathrm{~h}$. to estimate the percentage of morphological components the second sub-sample was separated manually into live leaf (PLL), live stem (PLS), and dead forage (PDF).

To estimate the total forage (TFA), live leaf (LLA) and live stem allowance (LSA), the total dry mass and the dry mass of the morphological components were divided by the $\mathrm{BW}$ of the animals in the paddocks. Manual grazing simulation was performed by harvesting one forage sample per paddock (hand-plucking), 
aiming to simulate, during grazing, the morphological composition of the herbage consumed by the cattle. A single person properly trained undertook this sampling by observing the herbage consumption of all animals in each paddock. Each sample was packed in a labeled plastic bag and, in the laboratory, their morphological samples were separated similarly to the procedures described to determine the mass of the pasture morphological components.

The selectivity of the animals (apparent selectivity index) for live leaf (ASIL), live stem (ASLS), and dead forage (ASDF) was calculated based on the formula proposed by Santos et al. (2011b), in which the percentage of morphological components from the manual grazing simulation is divided by the percentages of the morphological components of the deferred pasture.

The average daily weight gain (ADG) was calculated as the difference between the final and initial weights of the animals divided by the number of days between weighing sessions. The total daily weight gain per area (ADGA) was calculated based on the total weight gain per area, by dividing the weight accumulated in the period of use of the pastures, per hectare, by the number of grazing days.

To estimate the efficiency of conversion of fertilizer into forage (ECFF), the average forage

$$
Y_{i j k l}=\beta_{0}+\beta_{1} N_{i}+\beta_{2}\left(N_{i}^{2}\right)+\beta_{3} G_{j}+\beta_{4}\left(G_{j j}^{2}\right)+\beta_{5}(N \times G P)_{i j}+B_{k}+e_{i j}
$$

where: $\mathrm{N}_{\mathrm{i}}=$ nitrogen level (fixed effect); $\mathrm{GP}_{\mathrm{j}}=$ grazing period (random effect); $\mathrm{B}_{\mathrm{k}}=$ block (random effect); $\mathrm{N}_{\mathrm{i}} \times \mathrm{GP}_{\mathrm{j}}=$ interaction between $\mathrm{N}$ level and grazing period (random effect); $\mathrm{e}_{\mathrm{ij}}=$ overall error (random effect). Variables related to animal performance and efficiency of $\mathrm{N}$ fertilization were analyzed according to the following mixed model:

$$
Y_{i j k}=\mu+N+B_{k}+e_{i j}
$$

where: $\mathrm{N}=$ nitrogen (fixed effect); $\mathrm{B}_{\mathrm{k}}=$ block (random effect); and $\mathrm{e}_{\mathrm{ij}}=$ overall error (random effect).

The final models obtained were selected by excluding non-significant parameters $(\beta)$. The polynomial linear and quadratic contrasts of effects of $\mathrm{N}$ levels and grazing period on animal performance results were evaluated. For both mass of the unfertilized paddock was subtracted from the average forage mass of the fertilized paddock, and the result was divided by the respective $\mathrm{N}$ level. The data utilized in the calculation were those of forage mass at the end of the deferment period (beginning of the grazing period) and the respective fertilizer levels applied. The efficiency of conversion of fertilizer into animal product (ECAP) was estimated from the formula proposed by Martha Junior et al., (2004), in which the total ADG per area is divided by the respective $\mathrm{N}$ level, expressed later as kilograms of BW per kilogram of $\mathrm{N}$ applied.

Because the variables associated with the animal performance and the with efficiency of conversion of forage into animal product had only one average value per treatment, it was not possible to exploit the effect of grazing period, but only the effect of $\mathrm{N}$ level. The mean values of the other variables were grouped per grazing period (1st, 28th, 56th and 91st; and 1st, 28th, 56th, and 84th days for years 1 and 2, respectively).

Data were analyzed separately in the two experimental years by performing a multiple regression, with parameters estimated by the SOLUTION option of PROC MIXED procedure of SAS software (SAS..., 2009), using the Kenward-Roger approximation for the calculation of the residual degrees of freedom, based on the model below:

significance of parameters and polynomial contrasts, $\alpha=0.10$ was adopted.

\section{RESULTS}

Plant height, in the first year, was influenced by the interaction $(\mathrm{P}=0.005)$ of $\mathrm{N}$ level and GP, while in the second year, the $\mathrm{PH}$ was influenced only by GP $(\mathrm{P}<0.001)$. The interaction between $\mathrm{N}$ level and GP influenced the EPH in both years $(\mathrm{P}=0,087$ and $\mathrm{P}=0.009$, respectively).

No interaction $(\mathrm{P}=0.77)$ effect was found between $\mathrm{N}$ level and GP on the FI, which increased linearly $(\mathrm{P}<0.001)$ with the $\mathrm{N}$ level and showed a quadratic response $(\mathrm{P}=0.005)$ throughout the GP (Table 1). 
Beef cattle performance...

Table 1. Effect of nitrogen $(\mathrm{N})$ fertilization in the beginning of the signal grass deferment and grazing period (GP) on pasture characteristics

\begin{tabular}{|c|c|c|c|c|c|c|c|c|c|c|c|c|}
\hline \multirow{2}{*}{ Variables } & \multicolumn{4}{|c|}{$\mathrm{N}$ level $\left(\mathrm{kg} \mathrm{ha}^{-1}\right)$} & \multicolumn{4}{|c|}{ Grazing Period (days) } & \multicolumn{3}{|c|}{$P$ value } & \multirow[t]{2}{*}{ SEM } \\
\hline & 0 & 40 & 80 & 120 & 0 & 28 & 56 & 91 & $\mathrm{~N}$ & GP & $\mathrm{N} \times \mathrm{GP}$ & \\
\hline \multicolumn{13}{|c|}{ Year 1} \\
\hline $\mathrm{PH}, \mathrm{cm}$ & 36.7 & 37.4 & 38.3 & 36.8 & 67.0 & 32.8 & 27.3 & 22.2 & 0.196 & $<0.001 * *$ & 0.005 & 3.37 \\
\hline $\mathrm{EPH}, \mathrm{cm}$ & 48.9 & 66.1 & 64.0 & 71.3 & 93.4 & 61.9 & 52.0 & 43.3 & $0.053 * *$ & $<0.001 * *$ & 0.087 & 4.08 \\
\hline FI & 1.42 & 2.02 & 1.87 & 2.18 & 1.42 & 2.02 & 2.03 & 2.03 & $<0.001 *$ & $0.005 * *$ & 0.77 & 0.08 \\
\hline $\mathrm{FM}, \mathrm{t} \mathrm{ha}^{-1}$ & 6.90 & 8.2 & 9.1 & 12.2 & 13.3 & 8.3 & 7.5 & 7.3 & $0.026^{* *}$ & $0.001 * *$ & 0.003 & 0.71 \\
\hline $\begin{array}{l}\text { PLL, \% } \\
\text { of total } \\
\text { DM }\end{array}$ & 14.6 & 12.8 & 12.4 & 9.1 & 26.5 & 11.0 & 7.1 & 4.2 & $<0.001^{*}$ & $<0.001 * *$ & 0.001 & 1.8 \\
\hline $\begin{array}{l}\text { PLS, \% of } \\
\text { total DM }\end{array}$ & 33.9 & 43.9 & 42.7 & 44.1 & 43.8 & 44.1 & 36.0 & 40.6 & $0.032 * *$ & $0.006^{*}$ & 0.516 & 1.3 \\
\hline $\begin{array}{l}\text { PDF, \% } \\
\text { of total } \\
\text { DM }\end{array}$ & 47.2 & 45.3 & 45.1 & 45.1 & 30.1 & 44.9 & 46.1 & 59.8 & 0.52 & $<0.001 *$ & 0.052 & 2.3 \\
\hline $\begin{array}{l}\text { TFA, kg } \\
\mathrm{kg}^{-1} \text { of } \\
\text { BW }\end{array}$ & 15.1 & 17.9 & 16.3 & 28.1 & 28.9 & 18.0 & 15.6 & 14.9 & $0.002 * *$ & $0.005 * *$ & 0.004 & 1.7 \\
\hline $\begin{array}{l}\text { LLA, } \mathrm{kg} \\
\mathrm{kg}^{-1} \text { of } \\
\mathrm{BW}\end{array}$ & 2.5 & 2.6 & 2.8 & 2.9 & 7.2 & 1.8 & 1.1 & 0.67 & 0.773 & $<0.001 * *$ & 0.924 & 0.51 \\
\hline $\begin{array}{l}\text { LSA, kg } \\
\mathrm{kg}^{-1} \text { of } \\
\text { BW }\end{array}$ & 5.7 & 8.1 & 7.8 & 12.2 & 13.2 & 8.1 & 6.1 & 6.2 & $0.001 *$ & $0.018 * *$ & 0.034 & 0.90 \\
\hline ASIL & 1.94 & 1.71 & 1.88 & 1.92 & 1.94 & 1.91 & 0.99 & 2.62 & 0.98 & $0.002 *$ & 0.375 & 0.16 \\
\hline ASLS & 0.95 & 0.80 & 0.77 & 0.84 & 1.05 & 1.07 & 0.81 & 0.46 & 0.313 & $0.035 * *$ & 0.303 & 0.05 \\
\hline ASDF & 0.85 & 0.91 & 0.88 & 1.08 & 0.28 & 0.74 & 1.41 & 1.18 & 0.335 & $0.011 * *$ & 0.413 & 0.08 \\
\hline \multicolumn{13}{|c|}{ Year 2} \\
\hline $\mathrm{PH}, \mathrm{cm}$ & 36.6 & 37.0 & 36.6 & 39.8 & 57.3 & 36.0 & 31.0 & 25.8 & 0.237 & $<0.001 * *$ & 0.068 & 1.88 \\
\hline $\mathrm{EPH}, \mathrm{cm}$ & 45.0 & 46.9 & 48.4 & 53.3 & 69.0 & 50.7 & 43.5 & 37.2 & $<0.001 *$ & $<0.001 * *$ & 0.009 & 1.75 \\
\hline FI & 1.29 & 1.40 & 1.41 & 1.42 & 1.22 & 1.44 & 1.41 & 1.44 & 0.23 & $0.004 * *$ & 0.605 & 0.02 \\
\hline FM, t ha ${ }^{-1}$ & 5.7 & 6.1 & 7.1 & 8.0 & 8.1 & 7.0 & 6.0 & 5.8 & $0.001 * *$ & $0.005 * *$ & $<0.001$ & 25.8 \\
\hline $\begin{array}{l}\text { PLL, \% of } \\
\text { total DM }\end{array}$ & 18.0 & 13.1 & 12.6 & 13.2 & 29.5 & 18.2 & 8.9 & 2.2 & $0.016^{* *}$ & $0.001 * *$ & 0.024 & 1.5 \\
\hline $\begin{array}{l}\text { PLS, \% of } \\
\text { total DM }\end{array}$ & 37.5 & 41.3 & 38.9 & 39.3 & 41.0 & 44.8 & 37.6 & 33.6 & $0.030 * *$ & $0.081 * *$ & 0.055 & 1.0 \\
\hline $\begin{array}{l}\text { PDF, \% of } \\
\text { total DM }\end{array}$ & 45.3 & 50.9 & 51.7 & 49.3 & 34.7 & 41.9 & 53.3 & 63.7 & 0.293 & $<0.001 *$ & 0.212 & 1.9 \\
\hline $\begin{array}{l}\text { TFA, } \mathrm{kg} \\
\mathrm{kg}^{-1} \text { of BW }\end{array}$ & 11.8 & 13.1 & 14.2 & 16.6 & 18.1 & 14.2 & 12.1 & 11.4 & $<0.001 *$ & $0.025^{*}$ & 0.001 & 0.63 \\
\hline $\begin{array}{l}\text { LLA, } \mathrm{kg} \\
\mathrm{kg}^{-1} \text { of BW }\end{array}$ & 2.2 & 2.0 & 2.3 & 2.5 & 4.9 & 3.0 & 1.1 & 0.27 & $0.071 *$ & $<0.001 *$ & 0.125 & 0.27 \\
\hline $\begin{array}{l}\text { LSA, } \mathrm{kg} \\
\mathrm{kg}^{-1} \text { of BW }\end{array}$ & 4.6 & 5.9 & 5.7 & 6.3 & 6.4 & 7.5 & 4.8 & 3.8 & $0.025^{*}$ & $<0.001 *$ & 0.026 & 0.32 \\
\hline ASIL & 4.56 & 5.86 & 5.89 & 3.18 & 1.98 & 2.03 & 1.47 & 18.6 & 0.58 & $<0.001 *$ & 0.799 & 1.08 \\
\hline ASLS & 0.86 & 0.66 & 0.61 & 0.74 & 0.72 & 0.64 & 0.79 & 0.75 & 0.041 & $0.313^{*}$ & 0.694 & 0.03 \\
\hline ASDF & 0.80 & 0.79 & 0.83 & 0.65 & 0.41 & 0.88 & 1.13 & 0.56 & 0.474 & $<0.001 * *$ & 0.742 & 0.05 \\
\hline
\end{tabular}

* Linear effect; ** Quadratic effect; SEM - standard error of mean, ns - not significant. PH: Plant height; EPH: Extended plant height; FI: Fallen index; FM: Forage mass; PLL: Percentage of live leaves; PLS: Percentage of live stems; PDF: Percentage of dead forage; TFA: total forage allowance; LLA: live leaves allowance; LSA: Live stems allowance; ASIL: apparent selectivity index of live leaves; ASLS: apparent selectivity index of live stems; ASDF: apparent selectivity index of dead forage.

There was an interaction effect between $\mathrm{N}$ level and GP on FM in both evaluated years $(\mathrm{P}=0.003$ and $\mathrm{P}<0.001$, respectively) (Table 2). The interaction effect between $\mathrm{N}$ level and GP was also observed on the PLL in both years $(\mathrm{P}=0.001$ and $\mathrm{P}=0.024$, respectively) and on the PLS only in year $2(\mathrm{P}=0.055)$ (Table 1$)$. On the other hand, the PLS, in year 1 , was affected by the 
factors separately. The PLS in the first year, showed a quadratic response to the $\mathrm{N}$ level $(\mathrm{P}=$ 0.032 ) and decreased linearly throughout the GP $(\mathrm{P}=0.006)$. In the first year, PDF was influenced by the interaction of $\mathrm{N}$ levels and $\mathrm{GP}(\mathrm{P}=0.052)$; in the second year, the PDF $(\mathrm{P}<0.001)$ increased linearly with the GP (Table 1).

In years 1 and 2, the interaction between $\mathrm{N}$ levels and GP was detected on the TFA $(\mathrm{P}=0.004$ and $\mathrm{P}=0.001)$ and LSA $(\mathrm{P}=0.034$ and $\mathrm{P}=0.026)$ whereas the LLA were influenced negatively $(\mathrm{P}<$ $0.001)$ by the GP (Table 1). The ASIL (P= $0.002)$, ASLS $(\mathrm{P}=0.035)$ and ASDF $(\mathrm{P}<0.001)$ in the first year were influenced only by the GP (Table 1). In the second year, the ASIL and
ASDF had a linear response $(\mathrm{P}<0.001)$ only to GP, while the ASLS had a linear response $(\mathrm{P}=$ 0.041 ) to $\mathrm{N}$ levels (Table 1).

In the analysis of animal production, in year 1 no influence $(\mathrm{P}>0.10)$ of the $\mathrm{N}$ level was detected on $\mathrm{ADG}$ or on ADGA. In that year, only the ECFF and ECAP were influenced by the application of $\mathrm{N}$ (Table 2). The ECFF showed a linear and positive response pattern $(\mathrm{P}=0.024)$, whereas the ECAP decreased $(\mathrm{P}=0.037)$ linearly with the application of $\mathrm{N}$. In year 2 the ECFF was not influenced (P>0.10) by the $\mathrm{N}$ level applied, whereas the ADGA $(\mathrm{P}=0.099)$ and ECAP $(\mathrm{P}=0,028)$ responded quadratically (Table 2).

Tablele 2. Effect of nitrogen $(\mathrm{N})$ fertilization in the beginning of the signal grass deferment on animal performance and efficiency of supplementary nitrogen on animal performance

\begin{tabular}{lcccccccc} 
& Variables & \multicolumn{4}{c}{ N level $\left(\mathrm{kg} \mathrm{ha}^{-1}\right)$} & \multicolumn{2}{c}{ P-value } & SEM \\
& Year 1 & 0 & 40 & 80 & 120 & $\mathrm{~L}$ & $\mathrm{Q}$ & \\
\hline ADG & & & & & & & & \\
ADGA & 0.122 & 0.085 & 0.120 & 0.134 & 0.324 & 0.127 & 0.009 \\
ECFF & 0.600 & 0.483 & 0.530 & 0.75 & 0.332 & 0.154 & 0.070 \\
ECAP & - & 45.2 & 52.9 & 90.2 & 0.024 & - & 11.70 \\
& - & 1.04 & 0.57 & 0.54 & 0.037 & - & 0.090 \\
ADG & 0.438 & 0.551 & 0.466 & 0.440 & 0.754 & 0.232 & 0.020 \\
ADGA & 1.24 & 1.92 & 1.17 & 1.19 & 0.219 & 0.099 & 0.140 \\
ECFF & - & 30.9 & 29.8 & 56.4 & 0.681 & - & 8.40 \\
ECAP & - & 4.53 & 1.56 & 0.93 & 0.004 & - & 0.580 \\
\hline
\end{tabular}

*Linear effect; ** Quadratic effect; SEM - standard error of mean, ns - not significant. ADG: average daily gain; ADGA: average daily gain per area; ECFF: efficiency of conversion of fertilizer into forage; ECAP: efficiency of conversion of fertilizer into animal product.

\section{DISCUSSIONS}

For most of the variables, the effect of grazing period as well experimental year was observed. As the grazing period advanced the FM was reduced (Table 1), because it was consumed by the animals; additionally, there might have also been a negative accumulation of herbage (Pereira et al., 2011; Santos et al., 2011a), with a senescence rate higher than the growth rate, because in the winter the climatic conditions (cold and dryness) are unfavorable to plant growth (Figure 1).

The pastures subjected to $\mathrm{N}$ levels above $80 \mathrm{~kg}$ N.ha ${ }^{-1}$ developed faster than those that received lower amounts, which resulted in a larger FM as well as a higher PLS (Table 1) at the beginning of the deferment period. The pastures that received greater $\mathrm{N}$ levels probably had a leaf area index beyond critical. In this condition, there is greater competition for light among the tillers, whose main results are stem elongation and increased senescence of plant tissues (Barbosa et al., 2007). The plant elongates its stem to expose the younger leaves in the upper part of the sward, where there is more luminosity. In response to the greater shading at the base of the forage sward, live and older leaves start the senescence process, thereby reducing the PLL in the pasture (Table 1).

The increase in $\mathrm{N}$ levels at the beginning of the deferment period, with no reduction in the length of this period, probably caused the pastures to reach a similar response plateau at the end of the deferment period, especially for $\mathrm{PH}$ (Table 1), even if the maximum values of these response 
variables were achieved in shorter times proportionally to the $\mathrm{N}$ level utilized.

It is possible that the preference of animals for the leaves located at the upper portion of the pasture caused the average $\mathrm{PH}$ and $\mathrm{EPH}$ values to decrease throughout the GP (Table 1). Because selectivity affects the quantity of herbage suitable to animal intake FI, one of the characteristics interfering with the management recommendations, increased with the application of N. In this regard, Santos et al. (2009b) suggested determining critical values for $\mathrm{PH}$ from which the plants lodge when animals are grazing the pasture.

The observed higher TFA with the higher $(120 \mathrm{~kg}$ $\mathrm{ha}^{-1}$ ) $\mathrm{N}$ levels (Table 1) does not necessarily characterize an advantage, because these pastures also had the lowest PLL, the highest PLS and PDF (Table 1), and the FI (Table 1). This demonstrates that forage allowance does not express the quality of the pasture (Burns et al., 1989). The leaf live allowance was similar between the $\mathrm{N}$ levels in the first year (Table 1), probably because there was a compensation effect between FM and PLL as the level of $\mathrm{N}$ was elevated. Thus, the non-significance of the $\mathrm{N}$ effect on the LLA might have also contributed to the lack of significant effects on ADG and on animal production per unit of ADGA (Table 2).

The stocking rate could have been increased in the pastures in which the highest TFA were observed due to the application of the highest $\mathrm{N}$ level $\left(120 \mathrm{~kg} \mathrm{ha}^{-1}\right)$, aiming for the largest part of the produced forage to be grazed by the animals. However, increasing the stocking rate in these pastures would excessively facilitate the grazing losses. The longer walk of the animals on the pasture could increase FI and consequently herbage losses. Thus, over the course of the GP, the available herbage mass might not have been sufficient to meet the requirement of the animals, even with a high forage allowance.

A greater intake of live leaves is observed at the beginning of the deferment period because of the higher availability and especially because the leaf is the morphological component preferred by animals. In fact, among the morphological components, the live leaf showed the highest mean values for ASIL (Table 1). On the other hand, over the GP, with the reduction of TFA and LLA, the animals inevitably started to select stems and even dead herbage. In forage species like Brachiaria, which has a thin stem, despite being deprecated, this part can also be consumed, not posing a hindrance to seizure and consumption of the herbage compared with larger grasses. Thus, in the beginning of the GP, apparent selectivity indices close to one were observed for this morphological component (Table 1).

During the first experimental year, at the end of the GP, the ASIL were lower than one. This does not necessarily mean the leaves were deprecated by the animals, but that it was rather a consequence of the lower LLA and PLL, both in the total herbage and in the consumed forage, in addition to the possible difficulty in seizing it. The lack of significance of $\mathrm{N}$ levels on the variables LLA and ASIL provided similar ADG and ADGA in the first year (Table 2). In the second year, although no differences were observed $(\mathrm{P}>0.10)$ in $\mathrm{ADG}$, the $\mathrm{N}$ level of $40 \mathrm{~kg}$ $\mathrm{ha}^{-1}$ provided a higher ADG $\left(0.551 \mathrm{~kg} \mathrm{day}{ }^{-1}\right)$, which led to a higher ADGA (Table 2). Despite the lack of effects of the $\mathrm{N}$ levels on the animal performance, the $\mathrm{ADG}$ and $\mathrm{ADGA}$ are quite expressive, because the $\mathrm{BW}$ loss is common for animals in this period (Euclides et al., 2007; Silva et al., 2009). Even in pastures with a structure unfavorable to intake, the ADG of the animals in the dry period (Santos et al., 2009a) were positive. It highlights the importance of this strategy, which can be sufficient to provide a reduction of slaughter age.

The deferred pastures remained under free growth, which promotes, to a certain extent, higher efficiency of conversion of fertilizer into forage. In this context, the time the pastures spend deferred can be compared to the systems of utilization of forage plants under harvesting, in which the efficiency of the plant is usually high even with the application of elevated $\mathrm{N}$ levels. In this regard, Flores et al. (2012) observed increments in dry mass production and in the efficiency of the cuse of $\mathrm{N}$ by elephantgrass plants as the $\mathrm{N}$ level and the age at harvest were increased.

Even with a higher ECFF, obtained with higher $\mathrm{N}$ levels, this response did not necessarily result in higher ECAP in the first year, for instance (Table 2). The highest values for this trait were 
observed, in both years, at the $\mathrm{N}$ level of $40 \mathrm{~kg}$ $\mathrm{ha}^{-1}$. Despite showing a higher FM, as previously discussed, the pastures that received higher $\mathrm{N}$ levels $\left(120 \mathrm{~kg} \mathrm{ha}^{-1}\right)$ had an unfavorable structure for animal consumption, with a lower PLL and FI (Table 1). Therefore, this unfavorable pasture structure, in the first year, did not provide an increase in animal performance (Table 2), thereby reducing the ECAP as the $\mathrm{N}$ level was increased. Unlike what was observed in this trial, even with the increase in animal performance, it is not uncommon to observe a reduction in the ECAP as the level of fertilizer is increased (Soares and Restle, 2002; Lupatini et al., 2013).

\section{CONCLUSIONS}

A fixed deferment period with increasing levels of nitrogen fertilization on signal grass pastures does not influence the average daily gain per animal, reduces the efficiency of the nitrogen fertilizer and negatively changes the structural characteristics of the pasture.

\section{REFERENCES}

BARBOSA, R.A.; NASCIMENTO JÚNIOR, D.; EUCLIDES, V.P.B. et al. Tanzânia grass subjected to combinations of intensity and frequency of grazing. Pesqui. Agropecu. Bras., v.42, p.329-340, 2007.

BURNS, J.C.; LIPPKE, H.; FISHER, D.S. The relationship of herbage mass and characteristics to animal responses in grazing experiments. In: MARTEN, G.G. (Ed.). Grazing research: design, methodology and analysis. Wisconsin: CSSA, 1989. p.7-19. (Special Publication, n.6).

EUCLIDES, V.P.B.; MACEDO, M.C.M.; ZIMMER, A.H. Pasture characteristics of Panicum maximum cv. Tanzânia fertilized with nitrogen in the end of summer. Pesqui. Agropecu. Bras., v.42, p.1189-1198, 2007.

FLORES, R.A.; URQUIAGA, S.S.; ALVES, B.J.R., COLLIER, L.S. et al. Effect of nitrogen fertilizer and cutting age on the dry matter production of elephant grass in Savana. Rev. Bras. Eng. Agríc. Ambient., v.16, p.1282-1288, 2012.

LUPATINI, G.C.; RESTLE, J.; VAZ, R.Z.; VALENTE, A.V. et al. Beef cattle production on black oats and italian ryegrass pasture under nitrogen fertilization. Cienc. Anim. Bras., v.14, p.161-171, 2013.
MARTHA JÚNIOR, G. B.; CORSI, M.; TRIVELIN, P. C. O.; VILELA, L. et al. Perdas de amônia por volatilização em pastagem de capim-tanzânia adubada com uréia no verão. Rev. Bras. Zootec., v. 33, p. 22402247, 2004

PEREIRA, V.V.; FONSECA, D.M.; MARTUSCELLO, J.A.; BRAZ, T.G.S. et al. Morphogenic and structural characteristics of Panicum maximum Jacq. cv. Mombaça under three densities of fertilization with nitrogen. Rev. Bras. Zootec., v.40, p.2681-2689, 2011

SANTOS, M.E.R.; FONSECA, D.M.F.; BALBINO, E.M.; MONNERAT, J.P.I.S. et al. Deferred and fertilized signalgrass: forage production and characteristics. Rev. Bras. Zootec., v.38, p.650-656, $2009 b$.

SANTOS, M.E.R.; FONSECA, D.M.F.; EUCLIDES, V.P.B.; RIBEIRO JÚNIOR, J.I. et al. Bovine production on deferred signalgrass pastures. Rev. Bras. Zootec., v.38, p.635-642, 2009a.

SANTOS, M.E.R.; FONSECA, D.M.F.; GOMES, V.M.; GOMIDE, C.A.M. et al. Signalgrass under continuous stocking with fixed or variable height during the seasons: morphogenesis and dynamics of tissues. Rev. Bras. Zootec., v.40, p.2323-2331, 2011 a.

SANTOS, M.E.R.; FONSECA, D.M.F.; GOMES, V.M.; NASCIMENTO JUNIOR, D. et al. Signalgrass under continuous stocking with fixed or variable height during the seasons: tillering dynamic. Rev. Bras. Zootec., v.40, p.2332-2339, 2011 b.

SANTOS, M.E.R.; FONSECA, D.M.F.; MAGALHÃES, M.A.; SILVA, S.P. et al. Structure and nutritive value of deferred pasture of brachiaria decumbens $\mathrm{cv}$. Basilisk during the grazing period. Rev. Bras. Agropecu. Sust., v.1, p.117-128, 2011c.

SAS/STAT: user's guide. Version 9.2. Cary: SAS Institute, 2009. 7869p.

SILVA, F.F.; SÁ, J.F.; SCHIO, A.L.; ÍTAVO, L.C.V. et al. Grazing supplementation: availability and quality x supplementation levels x performance. Rev. Bras. Zootec., v.38, p.371-389, 2009.

SOARES, A.; RESTLE, J. Nitrogen fertilization on triticale plus italian ryegrass pasture under continuous stocking: nitrogen recovery and forage production efficiency. Rev. Bras. Zootec., v.31, p.43-51, 2002.

TEIXEIRA, F.A.; BONOMO, P.; PIRES, A.J.V.; SILVA, F.F. et al. Annual production and quality of Brachiaria decumbens pastures deferred and strategies nitrogen fertilization. Acta Sci. Anim. Sci., v.33, p.241248, 2011 